\title{
SOME ABSORPTION PROPERTIES OF CLAY BRICKS
}

\author{
By L. A. Palmer
}

\section{ABSTRACT}

A study of the absorption propertics of 10 manufacturers' bricks has been made. This investigation included a study of the extent of absorption during total immersion of the bricks in water both at boiling and at room temperatures, as well as the various rates of absorption during partial immersion of the specimens. Two empirical equations, one relating to total and the other to partial immersion, have been found to apply reasonably well to the data obtained.

\section{CONTENTS}

I. Introduction

1. Purpose of the investigation

2. Materials_........ 106

II. Absorption during total immersion

1. Method of Procedure

2. Results......... 107

3. Discussion of results

III. Rate of absorption during partial immersion

1. Method of procedure...... 118

2. Results_............ 118

3. Discussion of results

IV. General discussion.

V. General summary

VI. Acknowledgments_......... 127

\section{INTRODUCTION}

\section{PURPOSE OF THE INVESTIGATION}

The results of the investigation presented and discussed in this paper constitute the first step of an investigation, "Wet wall interiors," sponsored by the American Face Brick Association and being conducted at the National Bureau of Standards.

The data and discussion presented in this paper concern marketable bricks. The study has been restricted to the absorption properties of such bricks, taking into account not only the various degrees of water absorption under definite conditions but also the various rates of such absorption. Obviously these data are necessary if the various factors involved in the transmission of moisture through brick masonry are to be capable of a true analysis.

Frequent mention is being made of Kreüger's ${ }^{1}$ ratio, or as he terms it, "coefficient of water saturation." This is the ratio of the pore

1 H. Kreüger, "Utredning rorande klimatisk inverkan pä bjggnadsfasader" Ingeniörs Ventenspaka Akademien, No. 24, p. 73; 1923, 
space (within a building unit) that is filled with water during a definite period of partial and total immersion of the specimen to the total pore space (including sealed pores) of the specimen. H. G. Schurecht ${ }^{2}$ has used a ratio differing from that of Kreüger in that the apparent rather than the total porosity is considered. This "pore ratio," as used by Schurecht, is the percentage absorption (computed on the basis of the dry weight of the specimen) during 48 hours of total immersion of the specimen in water at room temperature divided by the percentage absorption during immersion of the specimen for five hours in boiling water. Essentially the Schurecht ratio alone (designated in this paper as $X$ ) has been evaluated from the data here presented. The procedure used by the author in the tests described herein was to continue total immersion of the brick in water at room temperature for a time such that the rate of gain in weight of the specimen was less than a gram during 24 hours. In no instance was this time less than 48 hours. In many cases it was 72 and 96 hours. A 7 rather than a 5 hour boiling period was another departure from Schurecht's procedure.

\section{MATERIALS}

Ten different manufacturers' bricks were studied. About 300 to 500 bricks were received from each of the 10 manufacturers. This number of bricks in each case, according to the manufacturer's statement, represented his "range"; that is, they were so selected from the kiln of bricks as to represent a vertical "cross section" of the kiln and included a number of the relatively soft-burned bricks in the kiln, a number of the hardest burned, and many that were distributed at various points between these two extreme conditions. In Table 1 are presented data showing the character of clays from which the bricks were made and how they were molded.

TABLE 1

\begin{tabular}{|c|c|c|}
\hline Manufacturer's No. & Types of clays used & Method of forming \\
\hline 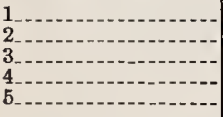 & \begin{tabular}{|l} 
Surface clay \\
Shale \\
Fire clay \\
Shale
\end{tabular} & $\begin{array}{l}\text { Dry-press. } \\
\text { Do. } \\
\text { Stiff-mud, side-cut. } \\
\text { Dry-press. } \\
\text { Do. }\end{array}$ \\
\hline $\begin{array}{l}6 \\
7 \\
8 \\
9 \\
10\end{array}$ & 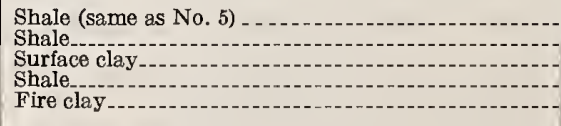 & $\begin{array}{l}\text { Stiff-mud, side-cut. } \\
\text { Do. } \\
\text { Soft-mud. } \\
\text { Stiff-mud, side-cut. } \\
\text { Do. }\end{array}$ \\
\hline
\end{tabular}

The fire clays used were not the typical high-grade fire clays used in the manufacture of refractory bricks.

S Senior fellow, National Terra Cotta Society research fellowship, National Bureau of Standards, Washington, D. C. Unpublished data. 


\section{ABSORPTION DURING TOTAL IMMERSION}

\section{METHOD OF PROCEDURE}

Each brick was first dried in a gas-fired oven (temperature $110^{\circ}$ to $160^{\circ}$ C.) for a time such that during an additional 24 hours in the oven any further loss in weight was less than $1 \mathrm{~g}$. They were then weighed on a balance sensitive to $\pm 1 \mathrm{~g}$. The dried bricks were then kept in a dry atmosphere until they were cooled to room temperature. This required at least 24 hours. They were then completely immersed in water at room temperature and for a time such that the gain in weight became less than $1 \mathrm{~g}$ during 24 hours.

Upon removing a brick from the water and prior to weighing it, four minutes' time was allowed during which the brick rested on its edge in a dry pan. It was then wiped quickly with a damp (neither dry nor saturated) towel and weighed. If the amount of moisture gained by the brick during its period of immersion was relatively small, it was put back into water after the first weighing and, after an elapse of a few minutes, was removed, wiped, and weighed again. If the two weighings differed by more than $2 \mathrm{~g}$ an average of several weighings was made following several repetitions of this procedure.

From a hundred or more of bricks of one type so tested there were selected a representative number of such for further tests. This number included those lowest and those highest in absorption as determined by the cold-absorption test, as well as several which absorbed amounts of water to an intermediate extent.

These selected bricks were then quickly transferred to boiling water and kept in such for a period of seven hours. By admitting warm water slowly and fairly constantly during this period loss from evaporation was replenished and the vigorous boiling was seldom interrupted. The bricks were then cooled, while still immersed, to room temperature and were weighed in the air. They were then weighed again while immersed in water at room temperature. The weight of each brick (saturated with water) minus its weight while suspended in water represented the bulk volume in milliliters of that brick. This was converted to cubic inches, and the brick volumes so recorded. The absorption during the cold immersion and that during boiling were expressed in grams of water per 65 cubic inches ${ }^{3}$ bulk volume of brick.

\section{RESULTS}

In the first column of Table 2 are given the numbers of individual bricks. In the second column, $Y$ denotes grams of water absorbed per 65 cubic inches of bulk volume of brick during the period of

${ }^{3} 65$ cubic inches is about the volume of a brick of average size. In specifieations brick dimensions are expressed in inches. 
cold immersion. This period ranged from 48 to 120 hours, depending upon the rate of absorption of the brick. As has already been mentioned, this test was terminated when it was found that the rate of gain in weight was less than $1 \mathrm{~g}$ during 24 hours. In the third column are given the number of grams of water absorbed per 65 cubic inches of bulk volume of brick following the 7 -hour boiling period. $Z$ (fourth column) denotes the difference between the $Y+Z$ value and the corresponding $Y$ value. $Z$ is then also computed on the basis of the volume, 65 cubic inches. Since $1 \mathrm{~g}$ of water occupies approximately a volume of $1 \mathrm{ml}$, all of the numbers under $Y, Y+Z$, and $Z$ may be considered as $\mathrm{ml}$. On this basis, $Y$ represents the $\mathrm{ml}$ of open pore space per 65 cubic inches of bulk volume of brick that can be entered by cold water during a certain time interval, $Y+Z$ represents the volume in $\mathrm{ml}$, of the pore space that was filled during the boiling tests, and $Z$ is the pore space that can be entered by boiling water, but which can not be entered by cold water. In the fifth column, $X$ is obtained by dividing the $Y$ value by the corresponding $Y+Z$ value. In the last column are recorded the results obtained by dividing each $Y$ value by the cube of $X$. The reason for so computing the data will be fully explained in the discussion following Table 2. The value, $K$, will hereafter be referred to as the "absorption constant."

TABLE 2.-Grams of water absorbed per 65 cubic inches bulk volume of brick during total immersion

BRICK NO. 1

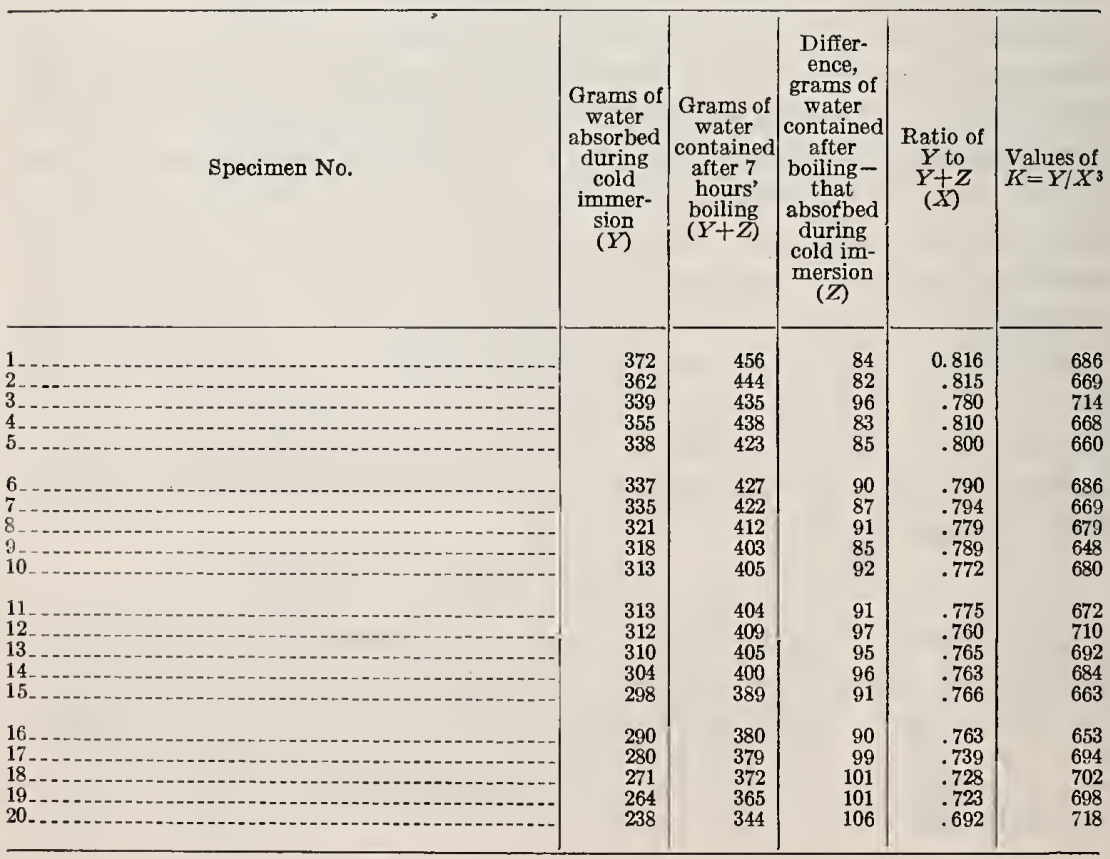


TABLE 2.-Grams of water absorbed per 65 cubic inches bulk volume of brick during total immersion-Continued

BRICK NO. 2

\begin{tabular}{|c|c|c|c|c|c|}
\hline Specimen No. & $\begin{array}{c}\text { Grams of } \\
\text { water } \\
\text { absorbed } \\
\text { during } \\
\text { cold } \\
\text { immer- } \\
\text { sion } \\
(Y)\end{array}$ & $\begin{array}{c}\text { Grams of } \\
\text { water } \\
\text { contained } \\
\text { after } 7 \\
\text { hours' } \\
\text { boiling } \\
(Y+Z)\end{array}$ & 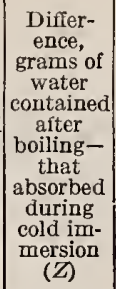 & $\begin{array}{c}\text { Ratio of } \\
Y \text { to } \\
Y+Z \\
(X)\end{array}$ & $\begin{array}{l}\text { Values of } \\
K=Y / X^{3}\end{array}$ \\
\hline $\begin{array}{l}1 \\
2 \\
4^{2}-20\end{array}$ & $\begin{array}{l}271 \\
268 \\
276 \\
257 \\
251\end{array}$ & $\begin{array}{l}319 \\
316 \\
327 \\
302 \\
305\end{array}$ & $\begin{array}{l}48 \\
48 \\
51 \\
45 \\
54\end{array}$ & $\begin{array}{l}0.850 \\
.846 \\
.845 \\
.850 \\
.823\end{array}$ & $\begin{array}{l}441 \\
440 \\
456 \\
417 \\
448\end{array}$ \\
\hline $\begin{array}{l}6 \\
70 \\
9\end{array}$ & $\begin{array}{l}224 \\
219 \\
209 \\
208 \\
206\end{array}$ & $\begin{array}{l}280 \\
273 \\
263 \\
267 \\
265\end{array}$ & $\begin{array}{l}56 \\
54 \\
54 \\
59 \\
59\end{array}$ & $\begin{array}{l}.800 \\
.802 \\
.795 \\
.779 \\
.777\end{array}$ & $\begin{array}{l}437 \\
427 \\
416 \\
440 \\
439\end{array}$ \\
\hline $\begin{array}{l}11 \\
12 \\
14 \\
15\end{array}$ & $\begin{array}{l}205 \\
202 \\
165 \\
143 \\
137\end{array}$ & $\begin{array}{l}256 \\
257 \\
223 \\
201 \\
200\end{array}$ & $\begin{array}{l}51 \\
55 \\
58 \\
58 \\
63\end{array}$ & $\begin{array}{l}.801 \\
.785 \\
.740 \\
.711 \\
.685\end{array}$ & $\begin{array}{l}401 \\
418 \\
407 \\
400 \\
426\end{array}$ \\
\hline
\end{tabular}

BRICK NO. 3

\begin{tabular}{|c|c|c|c|c|c|}
\hline $\begin{array}{l}1 \\
1\end{array}$ & $\begin{array}{l}191 \\
180 \\
173 \\
170 \\
165\end{array}$ & $\begin{array}{l}237 \\
224 \\
221 \\
211 \\
214\end{array}$ & $\begin{array}{l}46 \\
44 \\
48 \\
41 \\
49\end{array}$ & $\begin{array}{r}0.806 \\
.804 \\
.783 \\
.806 \\
.771\end{array}$ & $\begin{array}{l}365 \\
345 \\
360 \\
325 \\
360\end{array}$ \\
\hline $\begin{array}{l}6 \\
6\end{array}$ & $\begin{array}{l}158 \\
157 \\
166 \\
139 \\
118\end{array}$ & $\begin{array}{l}206 \\
205 \\
214 \\
186 \\
170\end{array}$ & $\begin{array}{l}48 \\
48 \\
48 \\
47 \\
52\end{array}$ & $\begin{array}{l}.767 \\
.766 \\
.776 \\
.746 \\
.694\end{array}$ & $\begin{array}{l}350 \\
349 \\
355 \\
335 \\
353\end{array}$ \\
\hline $\begin{array}{l}11 \\
13 \\
13 \\
15\end{array}$ & $\begin{array}{l}118 \\
115 \\
103 \\
102 \\
101\end{array}$ & $\begin{array}{l}168 \\
165 \\
155 \\
153 \\
153\end{array}$ & $\begin{array}{l}50 \\
50 \\
52 \\
51 \\
52\end{array}$ & $\begin{array}{r}.702 \\
.700 \\
.665 \\
.667 \\
.660\end{array}$ & $\begin{array}{l}341 \\
335 \\
350 \\
344 \\
351\end{array}$ \\
\hline 16 & $\begin{array}{l}93 \\
91 \\
91 \\
86\end{array}$ & $\begin{array}{l}146 \\
140 \\
141 \\
134\end{array}$ & $\begin{array}{l}53 \\
49 \\
50 \\
48\end{array}$ & $\begin{array}{l}.637 \\
.650 \\
.645 \\
.642\end{array}$ & $\begin{array}{l}359 \\
331 \\
339 \\
325\end{array}$ \\
\hline $\begin{array}{l}20 \\
22^{2}\end{array}$ & $\begin{array}{l}70 \\
62 \\
61 \\
58\end{array}$ & $\begin{array}{l}119 \\
102 \\
106 \\
107\end{array}$ & $\begin{array}{l}49 \\
40 \\
45 \\
49\end{array}$ & $\begin{array}{r}.588 \\
.608 \\
.575 \\
.542\end{array}$ & $\begin{array}{l}344 \\
276 \\
321 \\
364\end{array}$ \\
\hline
\end{tabular}

BRICK NO. 4

1
2
3
4
5
6
7
8
9
1

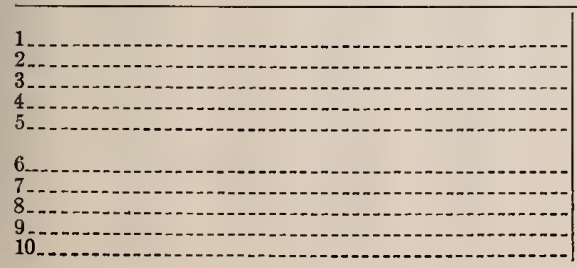

\begin{tabular}{l|l|}
233 & 275 \\
226 & 268 \\
224 & 265 \\
200 & 237 \\
194 & 240 \\
& \\
189 & 234 \\
184 & 227 \\
176 & 223 \\
174 & 214 \\
174 & 216
\end{tabular}

\begin{tabular}{l|l|l}
42 & 0.847 & 381 \\
42 & .843 & 377 \\
41 & .845 & 371 \\
37 & .844 & 333 \\
46 & .808 & 368 \\
& & \\
45 & .808 & 358 \\
43 & .810 & 346 \\
47 & .790 & 357 \\
40 & .813 & 324 \\
42 & .805 & 334
\end{tabular}


TABLE 2.-Grams of water absorbed per 65 cubic inches bulk volume of brick during total immersion-Continued

BRICK NO. 4-Continued

\begin{tabular}{|c|c|c|c|c|c|}
\hline \multirow[t]{4}{*}{ Specimen No. } & $\begin{array}{l}\text { Grams of } \\
\text { Water } \\
\text { absorbed } \\
\text { during } \\
\text { cold } \\
\text { immer- } \\
\text { sion } \\
(Y)\end{array}$ & $\begin{array}{l}\text { Qrams of } \\
\text { water } \\
\text { contained } \\
\text { after } 7 \\
\text { hours' } \\
\text { boiling } \\
(Y+Z)\end{array}$ & $\begin{array}{c}\text { Differ- } \\
\text { ence, } \\
\text { grams of } \\
\text { water } \\
\text { contained } \\
\text { after } \\
\text { boiling- } \\
\text { that } \\
\text { absorbed } \\
\text { during } \\
\text { cold im- } \\
\text { mersion } \\
(Z)\end{array}$ & $\begin{array}{c}\text { Ratio of } \\
Y \text { to } \\
Y+Z \\
(X)\end{array}$ & $\begin{array}{l}\text { Values of } \\
K=Y / X^{3}\end{array}$ \\
\hline & $\begin{array}{l}169 \\
162 \\
162 \\
154 \\
153\end{array}$ & $\begin{array}{l}214 \\
205 \\
203 \\
201 \\
197\end{array}$ & $\begin{array}{l}45 \\
43 \\
41 \\
47 \\
44\end{array}$ & $\begin{array}{l}0.789 \\
.790 \\
.800 \\
.766 \\
.776\end{array}$ & $\begin{array}{l}344 \\
329 \\
316 \\
343 \\
327\end{array}$ \\
\hline & $\begin{array}{l}148 \\
142 \\
137 \\
131 \\
122\end{array}$ & $\begin{array}{l}192 \\
183 \\
182 \\
179 \\
168\end{array}$ & $\begin{array}{l}44 \\
41 \\
45 \\
48 \\
46\end{array}$ & $\begin{array}{l}.770 \\
.776 \\
.755 \\
.732 \\
.726\end{array}$ & $\begin{array}{l}326 \\
304 \\
318 \\
338 \\
319\end{array}$ \\
\hline & $\begin{array}{r}102 \\
101 \\
100 \\
96 \\
90\end{array}$ & $\begin{array}{l}153 \\
154 \\
152 \\
147 \\
141\end{array}$ & $\begin{array}{l}51 \\
53 \\
52 \\
51 \\
51\end{array}$ & $\begin{array}{l}.667 \\
.658 \\
.658 \\
.653 \\
.638\end{array}$ & $\begin{array}{l}344 \\
355 \\
351 \\
345 \\
346\end{array}$ \\
\hline
\end{tabular}

BRICK NO. 5

\begin{tabular}{|c|c|c|c|c|c|}
\hline 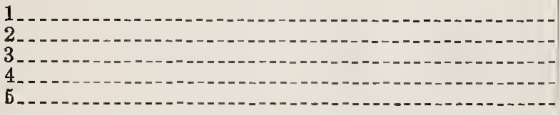 & $\begin{array}{l}287 \\
289 \\
283 \\
281 \\
282\end{array}$ & $\begin{array}{l}339 \\
340 \\
333 \\
334 \\
336\end{array}$ & $\begin{array}{l}52 \\
51 \\
50 \\
53 \\
54\end{array}$ & $\begin{array}{r}0.847 \\
.850 \\
.850 \\
.842 \\
.839\end{array}$ & $\begin{array}{l}472 \\
476 \\
461 \\
471 \\
477\end{array}$ \\
\hline $\begin{array}{l}6 \\
6 \\
6 \\
\end{array}$ & $\begin{array}{l}277 \\
277 \\
272 \\
271 \\
269\end{array}$ & $\begin{array}{l}329 \\
334 \\
328 \\
327 \\
321\end{array}$ & $\begin{array}{l}52 \\
57 \\
56 \\
56 \\
52\end{array}$ & $\begin{array}{l}.842 \\
.829 \\
.829 \\
.829 \\
.838\end{array}$ & $\begin{array}{l}464 \\
486 \\
477 \\
476 \\
457\end{array}$ \\
\hline 11 11 112 & $\begin{array}{l}269 \\
252 \\
252 \\
239 \\
232\end{array}$ & $\begin{array}{l}322 \\
309 \\
308 \\
295 \\
294\end{array}$ & $\begin{array}{l}53 \\
57 \\
56 \\
56 \\
62\end{array}$ & $\begin{array}{l}.835 \\
.816 \\
.817 \\
.810 \\
.789\end{array}$ & $\begin{array}{l}462 \\
464 \\
462 \\
450 \\
472\end{array}$ \\
\hline 16 & $\begin{array}{l}230 \\
229 \\
222 \\
221\end{array}$ & $\begin{array}{l}288 \\
282 \\
289 \\
284\end{array}$ & $\begin{array}{l}58 \\
53 \\
67 \\
63\end{array}$ & $\begin{array}{l}.800 \\
.812 \\
.767 \\
.778\end{array}$ & $\begin{array}{l}450 \\
428 \\
492 \\
469\end{array}$ \\
\hline $\begin{array}{l}20 \\
21 \\
23\end{array}$ & $\begin{array}{l}221 \\
220 \\
218 \\
197\end{array}$ & $\begin{array}{l}277 \\
282 \\
276 \\
264\end{array}$ & $\begin{array}{l}56 \\
62 \\
58 \\
67\end{array}$ & $\begin{array}{l}.800 \\
.781 \\
.790 \\
.746\end{array}$ & $\begin{array}{l}432 \\
462 \\
442 \\
474\end{array}$ \\
\hline
\end{tabular}

BRICK NO. 6

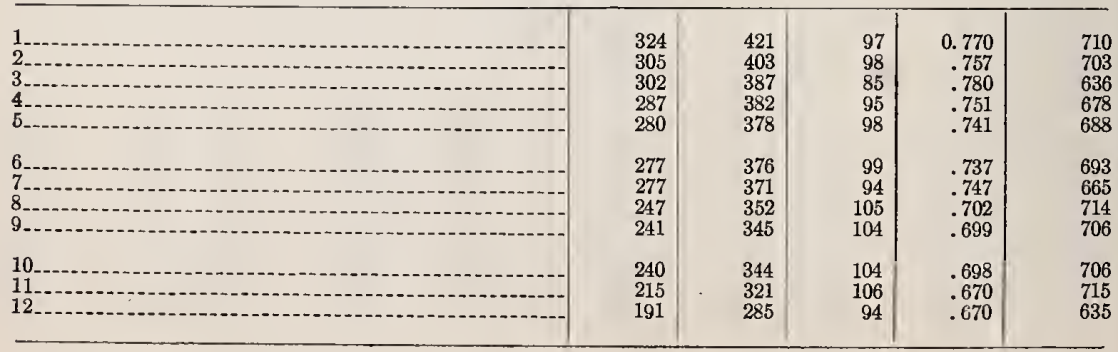


TABLE 2.-Grams of water absorbed per 65 cubic inches bulk volume of brick during total immersion-Continued

BRICK NO. 7

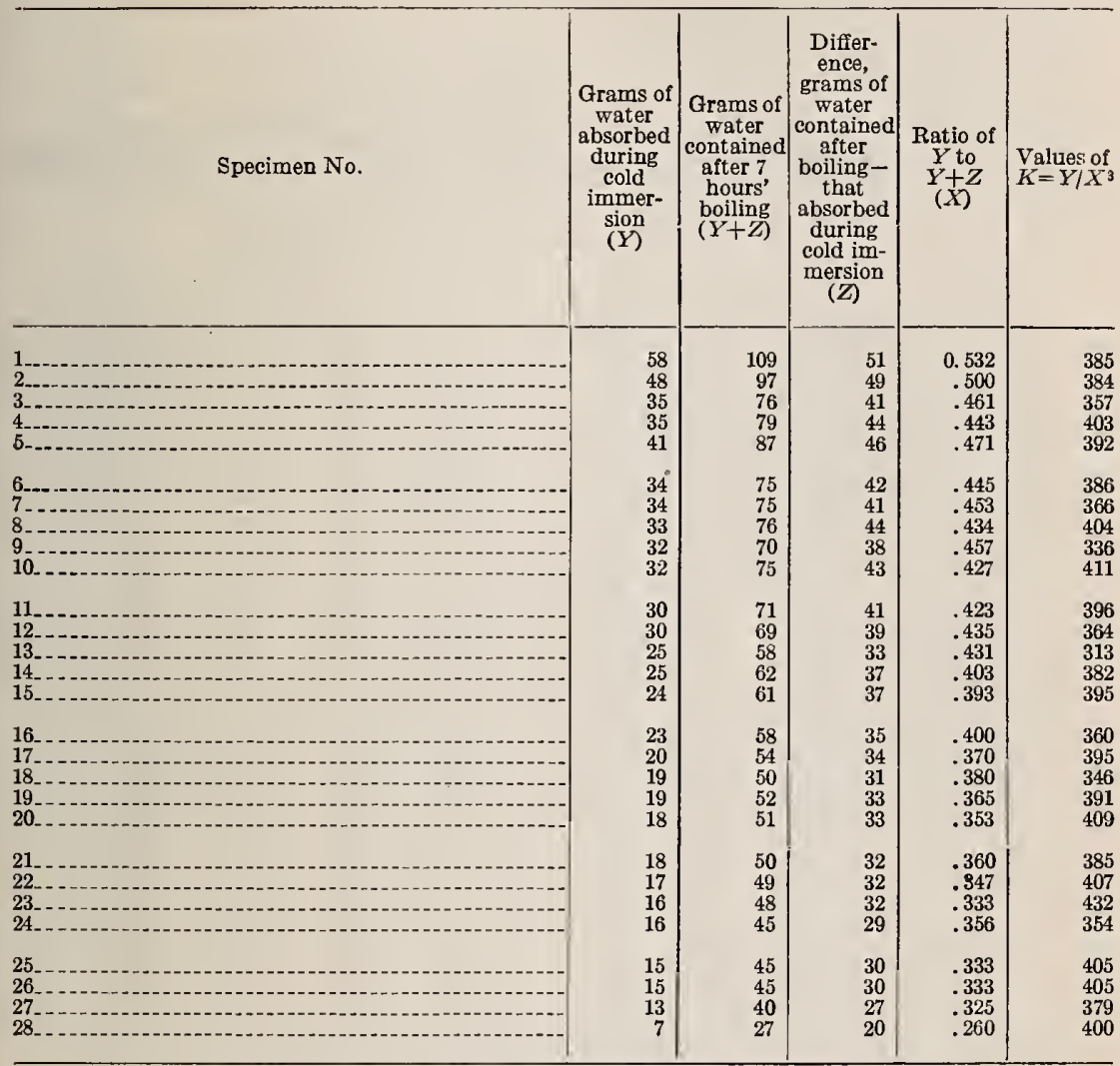

BRICK NO. 8

\begin{tabular}{|c|c|c|c|c|c|}
\hline 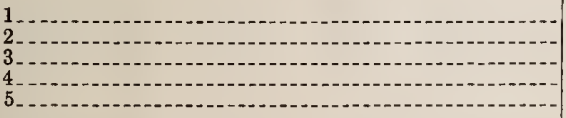 & $\begin{array}{l}249 \\
247 \\
231 \\
230 \\
227\end{array}$ & $\begin{array}{l}303 \\
303 \\
297 \\
294 \\
285\end{array}$ & $\begin{array}{l}54 \\
56 \\
66 \\
64 \\
58\end{array}$ & $\begin{array}{r}0.822 \\
.815 \\
.778 \\
.782 \\
.793\end{array}$ & $\begin{array}{l}449 \\
456 \\
491 \\
481 \\
455\end{array}$ \\
\hline $\begin{array}{l}6 \\
6\end{array}$ & $\begin{array}{l}179 \\
172 \\
152 \\
144\end{array}$ & $\begin{array}{l}240 \\
239 \\
220 \\
212\end{array}$ & $\begin{array}{l}61 \\
67 \\
68 \\
68\end{array}$ & $\begin{array}{l}.729 \\
.720 \\
.690 \\
.679\end{array}$ & $\begin{array}{l}462 \\
461 \\
462 \\
462\end{array}$ \\
\hline $11^{10}$ & $\begin{array}{r}132 \\
101 \\
95 \\
91\end{array}$ & $\begin{array}{l}203 \\
165 \\
151 \\
154\end{array}$ & $\begin{array}{l}71 \\
64 \\
56 \\
63\end{array}$ & $\begin{array}{l}.650 \\
.612 \\
.629 \\
.591\end{array}$ & $\begin{array}{l}480 \\
436 \\
392 \\
441\end{array}$ \\
\hline 16 & $\begin{array}{l}90 \\
80 \\
73 \\
44\end{array}$ & $\begin{array}{r}152 \\
137 \\
124 \\
93\end{array}$ & $\begin{array}{l}62 \\
57 \\
51 \\
49\end{array}$ & $\begin{array}{l}.592 \\
.584 \\
.588 \\
.473\end{array}$ & $\begin{array}{l}434 \\
402 \\
360 \\
416\end{array}$ \\
\hline
\end{tabular}

$53811^{\circ}-29-8$ 
TABLE 2.-Grams of water absorbed per 65 cubic inches bulk volume of brick during total immersion-Continued

BRICK NO. 9

\begin{tabular}{|c|c|c|c|c|c|}
\hline Specimen No. & $\begin{array}{l}\text { Grams of } \\
\text { water } \\
\text { absorbed } \\
\text { during } \\
\text { cold } \\
\text { immer- } \\
\text { sion } \\
(Y)\end{array}$ & $\begin{array}{c}\text { Grams of } \\
\text { water } \\
\text { contained } \\
\text { after 7 } \\
\text { hours' } \\
\text { boiling } \\
(Y+Z)\end{array}$ & $\begin{array}{c}\text { Differ- } \\
\text { ence, } \\
\text { grams of } \\
\text { water } \\
\text { contained } \\
\text { after } \\
\text { boiling- } \\
\text { that } \\
\text { absorbed } \\
\text { during } \\
\text { cold im- } \\
\text { mersion } \\
(Z)\end{array}$ & $\begin{array}{l}\text { Ratio of } \\
Y \text { to } \\
Y+Z \\
(X)\end{array}$ & $\begin{array}{l}\text { Values of } \\
K=Y \mid X^{3}\end{array}$ \\
\hline 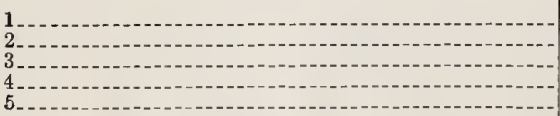 & $\begin{array}{l}\mathbf{1 6 5} \\
135 \\
133 \\
130 \\
\mathbf{1 3 1}\end{array}$ & $\begin{array}{l}209 \\
182 \\
178 \\
180 \\
178\end{array}$ & $\begin{array}{l}44 \\
47 \\
45 \\
50 \\
47\end{array}$ & $\begin{array}{r}0.790 \\
.742 \\
.747 \\
.722 \\
.736\end{array}$ & $\begin{array}{l}335 \\
330 \\
319 \\
345 \\
328\end{array}$ \\
\hline 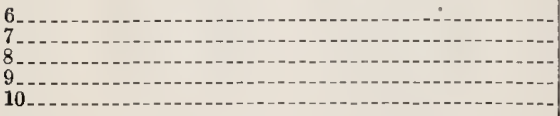 & $\begin{array}{l}130 \\
125 \\
124 \\
122 \\
118\end{array}$ & $\begin{array}{l}176 \\
175 \\
173 \\
173 \\
168\end{array}$ & $\begin{array}{l}46 \\
50 \\
49 \\
51 \\
50\end{array}$ & $\begin{array}{l}.735 \\
.717 \\
.716 \\
.705 \\
.702\end{array}$ & $\begin{array}{l}328 \\
339 \\
338 \\
348 \\
\mathbf{3 4 1}\end{array}$ \\
\hline $\begin{array}{l}11 \\
13 \\
13 \\
15\end{array}$ & $\begin{array}{l}115 \\
112 \\
107 \\
107 \\
107\end{array}$ & $\begin{array}{l}164 \\
162 \\
160 \\
158 \\
161\end{array}$ & $\begin{array}{l}49 \\
50 \\
53 \\
51 \\
54\end{array}$ & $\begin{array}{l}.701 \\
.690 \\
.671 \\
.677 \\
.665\end{array}$ & $\begin{array}{l}335 \\
341 \\
354 \\
345 \\
367\end{array}$ \\
\hline 16 & $\begin{array}{r}105 \\
104 \\
95 \\
92 \\
92\end{array}$ & $\begin{array}{l}156 \\
155 \\
146 \\
145 \\
143\end{array}$ & $\begin{array}{l}51 \\
51 \\
51 \\
53 \\
51\end{array}$ & $\begin{array}{l}.673 \\
.671 \\
.651 \\
.634 \\
.643\end{array}$ & $\begin{array}{l}344 \\
344 \\
344 \\
361 \\
346\end{array}$ \\
\hline $\begin{array}{l}21 \\
22 \\
23 \\
24\end{array}$ & $\begin{array}{l}88 \\
83 \\
80 \\
75\end{array}$ & $\begin{array}{l}138 \\
134 \\
127 \\
125\end{array}$ & $\begin{array}{l}50 \\
51 \\
47 \\
50\end{array}$ & $\begin{array}{l}.638 \\
.619 \\
.623 \\
.597\end{array}$ & $\begin{array}{l}338 \\
350 \\
331 \\
352\end{array}$ \\
\hline 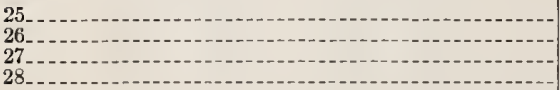 & $\begin{array}{l}70 \\
64 \\
63 \\
60\end{array}$ & $\begin{array}{l}119 \\
109 \\
111 \\
107\end{array}$ & $\begin{array}{l}49 \\
45 \\
48 \\
47\end{array}$ & $\begin{array}{l}.588 \\
.583 \\
.566 \\
.561\end{array}$ & $\begin{array}{l}344 \\
323 \\
348 \\
339\end{array}$ \\
\hline
\end{tabular}

BRICK NO. 10

\begin{tabular}{|c|c|c|c|c|c|}
\hline 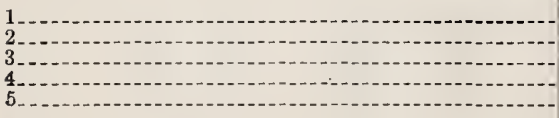 & $\begin{array}{l}154 \\
141 \\
138 \\
125 \\
123\end{array}$ & $\begin{array}{l}243 \\
228 \\
226 \\
211 \\
209\end{array}$ & $\begin{array}{l}89 \\
87 \\
88 \\
86 \\
86\end{array}$ & $\begin{array}{r}0.634 \\
.617 \\
.610 \\
.592 \\
.584\end{array}$ & $\begin{array}{l}604 \\
600 \\
608 \\
602 \\
618\end{array}$ \\
\hline $\begin{array}{l}6 \\
6 \\
\end{array}$ & $\begin{array}{l}113 \\
111 \\
110 \\
100\end{array}$ & $\begin{array}{l}193 \\
196 \\
192 \\
181\end{array}$ & $\begin{array}{l}80 \\
85 \\
82 \\
81\end{array}$ & $\begin{array}{l}.585 \\
.566 \\
.573 \\
.552\end{array}$ & $\begin{array}{l}564 \\
612 \\
585 \\
595\end{array}$ \\
\hline $11^{1} 11^{1}$ & $\begin{array}{r}100 \\
97 \\
94 \\
83\end{array}$ & $\begin{array}{l}178 \\
177 \\
174 \\
161\end{array}$ & $\begin{array}{l}78 \\
80 \\
80 \\
78\end{array}$ & $\begin{array}{l}.562 \\
.548 \\
.540 \\
.516\end{array}$ & $\begin{array}{l}563 \\
589 \\
597 \\
604\end{array}$ \\
\hline 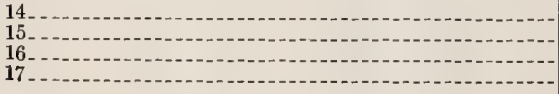 & $\begin{array}{l}72 \\
71 \\
63 \\
62\end{array}$ & $\begin{array}{l}145 \\
149 \\
132 \\
133\end{array}$ & $\begin{array}{l}73 \\
78 \\
69 \\
71\end{array}$ & $\begin{array}{l}.497 \\
.477 \\
.476 \\
.465\end{array}$ & $\begin{array}{l}586 \\
654 \\
584 \\
617\end{array}$ \\
\hline $\begin{array}{l}18 \\
19 \\
21\end{array}$ & $\begin{array}{l}59 \\
50 \\
47 \\
44\end{array}$ & $\begin{array}{l}124 \\
114 \\
112 \\
105\end{array}$ & $\begin{array}{l}65 \\
64 \\
65 \\
61\end{array}$ & $\begin{array}{r}.475 \\
.440 \\
.419 \\
.418\end{array}$ & $\begin{array}{l}550 \\
587 \\
639 \\
602\end{array}$ \\
\hline
\end{tabular}




\section{DISCUSSION OF RESULTS}

The various $Y$ values of 8 of the 10 types of bricks are plotted against their corresponding $X$ ratios on a logarithmic scale in Figures 1 and 2. The data for bricks Nos. 4 and 5, if plotted, would coincide with those of Nos. 3 and 2, respectively. By so plotting these data, it is noted that straight lines which are practically parallel to one another are obtained; that is, the slope is about the same and very nearly equal to 3 in all cases. The intercepts of any of these lines

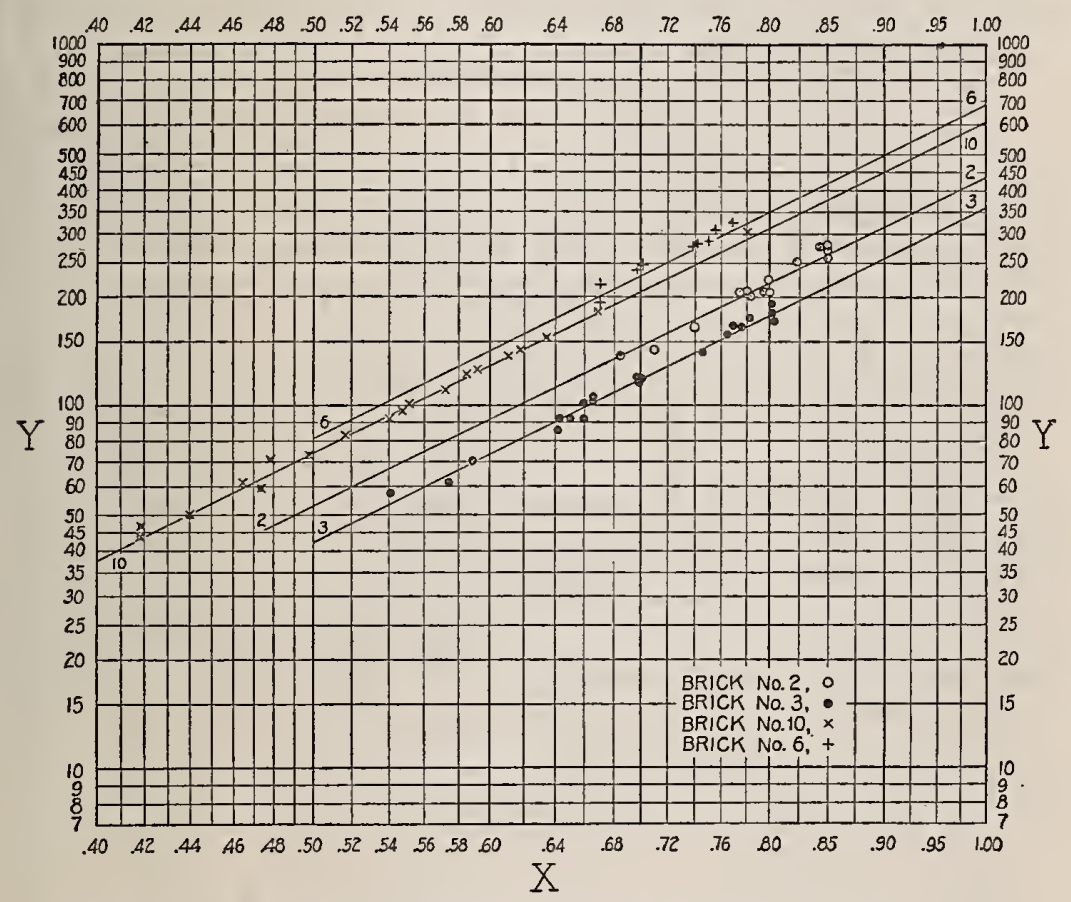

FIGURE 1.-Values of $Y$ plotted against corresponding values of $X$, on logarithmic scale

on the ordinate axis $(X=1)$ denote the absorption constants ( $K$ values) as obtained graphically. Starting with the equation

$$
Y=K X^{3}
$$

since $X=\frac{Y}{Y+Z}$, or $Y(1-X)=X Z$, and $Y=\frac{X Z}{(1-X)}$, there results by substitution in equation (1)

$$
Z=K\left(X^{2}-X^{3}\right)
$$

It is obvious that $X$ can not have negative values, and it is further evident that all of the values of $X$ will be greater than zero and less 


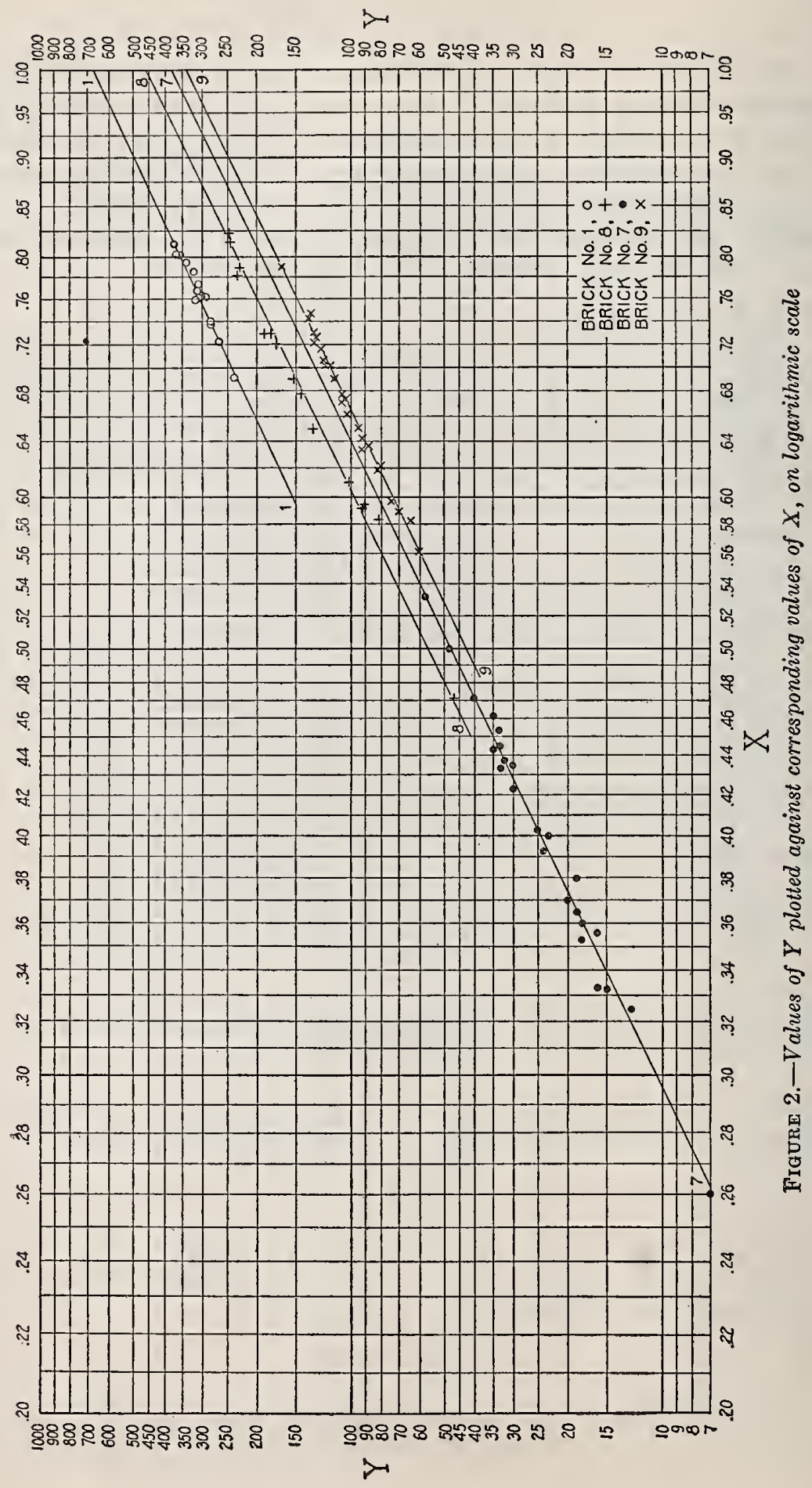


than unity for the type of material studied. From equation (2) when $X$ is zero, $Z$ also is zero, and when $X$ is unity, $Z$ is zero. Since $X$ can not be greater than one, $Z$ can have no negative values. $Z$ must, therefore, have a maximum value, since the curve from $X=0$ to $X=1$ is continuous. When $Z$ is a maximum, $\frac{d Z}{d X}$ is zero. Differentiating equation (2) with respect to $X$ gives

$$
\frac{d Z}{d X}=K X(2-3 X)
$$

Between the limits, $X=0$ and $X=1$, therefore, it is evident from equation (3) that $\frac{d Z}{d X}=0$ when $X=2 / 3$, and hence $Z$ has its greatest magnitude at this point.

It would be difficult to assign a physical reason for this fact. One thing, however, is indicated, and this is that with increasing temperature in the kiln the pore structure of an individual brick changes more or less according to some fundamental law that may be expressed mathematically. The relatively harder burned bricks have the lower and the softer burned ones the higher $X$ ratio. Between these extremes of burning conditions $X$ may have a value, $2 / 3$, at which $Z$, which might be called the residual porosity, is at a maximum.

As an example, consider brick No. 3. The softest-burned specimen is No. 1 with an $X$ ratio of 0.806 , and the hardest-burned one is No. 23 with an $X$ ratio of 0.542 . The corresponding $Z$ values for the two bricks are 46 and 49, respectively. However, specimens 10, 11, 12, 13 , and 14, which represent neither the softest nor the hardest burned of the 23 bricks, have the $X$ ratios, $0.694,0.702,0.700,0.665$, and 0.667 and the corresponding $Z$ values, $52,50,50,52$, and 51 . It may be further noted that throughout Table 2 the various $Z$ values are highest for $X$ ratios ranging from 0.600 to 0.700 in all cases where this range is covered.

Certain corollaries follow from equations (1) and (2). These are-

1. $Z$ reaches a maximum when $X=2 / 3$ as shown above.

2. From equation (1), $Y=Y+Z=K$ when $X=1$.

3. When $Z$ is a maximum, $Y=$ twice maximum $Z$. For since $Y=\frac{X Z}{1-X}$, and since $Z$ is at a maximum when $X=2 / 3$, then $Y=\frac{(2 / 3) Z \text { maximum }}{1-2 / 3}=2 Z_{\max }$.

4. $K=6^{3 / 4}$ times $Z_{m a x}$. From equation (1), $Y=(2 / 3)^{3} K$ when $X=2 / 3$, and since $Y=2 Z_{\max }$ at this point, then $2 Z_{\max .}=(2 / 3)^{3} K$, or $K=6^{3 / 4}$ times $Z_{\max }$.

These corollaries may now be applied to the data of Table 2. A few typical cases may be noted. In the following brief recapitulation 
of a few of the results, figures in the fifth column are obtained by multiplying the $Z$ value corresponding to an $X$ ratio of $2 / 3$ (charac-

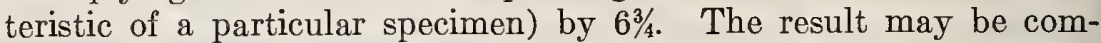
pared with the corresponding $K$ (sixth column), which is the average value for the type of brick considered.

TABLE 3

\begin{tabular}{|c|c|c|c|c|c|c|c|}
\hline Brick No. & $\begin{array}{c}\text { Speci- } \\
\text { men } \\
\text { No. }\end{array}$ & $X$ & $Z_{\max }$ & $\stackrel{(63 / 4)}{Z_{\max } .}$ & $\begin{array}{c}K \\
\text { (average) }\end{array}$ & $2 Z_{\max }$ & $\begin{array}{l}Y \text { corre- } \\
\text { sponding } \\
\text { to } Z_{\text {max. }}\end{array}$ \\
\hline 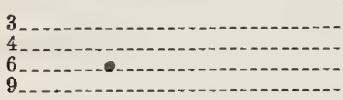 & (3) $\begin{array}{r}14 \\
22 \\
11\end{array}$ & $\begin{array}{r}0.667 \\
.667 \\
.670 \\
.669\end{array}$ & $\begin{array}{r}51 \\
51 \\
106 \\
53\end{array}$ & $\begin{array}{l}344 \\
344 \\
716 \\
358\end{array}$ & $\begin{array}{l}342 \\
338 \\
687 \\
341\end{array}$ & $\begin{array}{l}102 \\
102 \\
212 \\
106\end{array}$ & $\begin{array}{l}102 \\
102 \\
215 \\
106\end{array}$ \\
\hline
\end{tabular}

1 A verage of Nos. 13, 15, and 17.

The figures in the seventh column compare favorably with the corresponding figures of the eighth, illustrating the applicability of corollary 3 to the data of Table 2.

The values of $Z$ in the data for the other six types of bricks, not listed above, are seen to increase in every case as $X$ approaches more and more closely to 0.667 .

It is apparent also from a study of Table 2 that one manufacturer's single brick made from a certain clay or shale and molded by a particular process may have the same $X$ ratio as that of another individual brick made by a different manufacturer from a different clay or shale, yet the degree of absorption of the two bricks differ markedly. A few examples will serve to illustrate this point.

TABLE 4

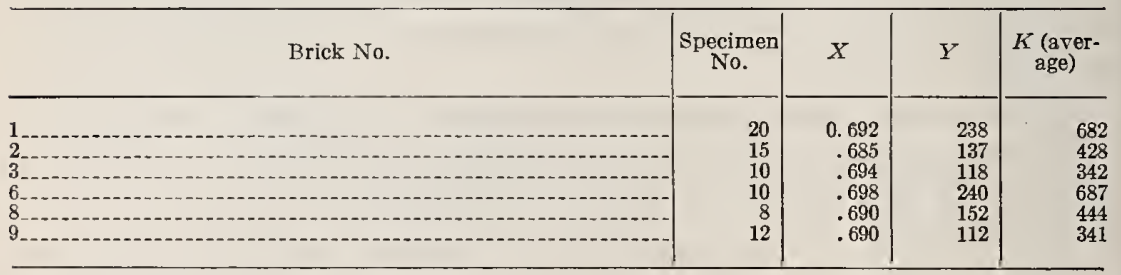

In this connection, note that sample 20 , type No. 1 , is a brick made from surface clay, molded by the dry-press process, whereas sample 12 of type No. 9 is a brick made from shale aud molded by the stiffmud process. The absorption constant, $K$, of No. 1 is approximately equal to that of No. 6.

Since $K$ in any case equals $\left(6 \frac{3}{4}\right) Z_{\max }$., it is evident that the greater is $K$ for any manufacturer's brick, the greater also (relatively) is $Z_{\text {max }}$. Also, since the $Y$ corresponding to $Z_{\max }$. is equal to twice $Z_{m a x}$. it follows that for a given Schurecht ratio, $X$, types of bricks 
having the relatively larger absorption constants are relatively more absorbent than are the types of bricks having the lower constants.

Whatever $K$ for a particular type of brick may be dependent upon, it is apparently independent of the heat treatment which the brick received over a certain range of temperature at least. The bricks of any of the 10 types of Table 2 having the five largest $Y$ and $Y+Z$ values are numbered from 1 to 5 in each case. These bricks were taken by the manufacturer from the lower portions of the down-draft kiln where the temperature during firing is usually lowest. The bricks of any of the 10 types designated by numbers higher than 10 are harder burned. These were selected from the tops of the kilns. They have lower $Y$ and $Y+Z$ values, are darker in color, and are slightly smaller than are the softer burned bricks, yet both the relatively soft and the relatively hard burned bricks of any one type have the same absorption constant, $K$. The value, $K$, is apparently characteristic of a type of brick over a comparatively wide range of firing temperature.

Nothing has been done as yet to determine the limits in degree of burning beyond which the relation, $Y=K X^{3}$, ceases to hold. It was found to obtain among the 10 types of bricks over a relatively wide range of burning, but yet for marketable bricks only. None of these bricks have the appearance of being distinctly underburned or overburned. All of the water which any of the bricks absorbed during boiling was lost upon drying them at $100^{\circ}$ to $110^{\circ} \mathrm{C}$., and when placed in a chamber of 95 to 100 per cent relative humidity, none of these bricks, initially dry, gained as much as a gram of water during a week's time, thus indicating that there was no appreciable hydration or adsorption. It is possible that a brick that is distinctly underburned may hydrate and adsorb moisture. This is indicated in the results obtained by Washburn. ${ }^{4}$ It has been further shown by McBain and Ferguson ${ }^{5}$ that bricks burned at relatively high temperatures adsorb little or no moisture when kept in an atmosphere of high relative humidity. When there is an appreciable amount of hydration and adsorption together with absorption, it does not seem likely that the symmetrical relation, $Y=K X^{3}$, would apply.

\section{RATE OF ABSORPTION DURING PARTIAL IMMERSION}

In the study of the various factors involved in the transmission of water through brick masonry it is necessary to know the rate as well as the total extent of water absorption.

Aside from noting the approximate time required for water to wet the total length, breadth, or thickness of the brick, no attempt was

Edward W. Washburn and Frank F. Footitt, J. Am. Cer. Soc., 4 (12), p. 974; 1921.

S McBain and Ferguson, J. Phys. Chem., 31 (4), pp. 562-594; 1927. 
made to study rates of water penetration from the standpoint of any other distance versus time relationship. It was found to be exceedingly difficult to know in many cases when water "struck through"; that is, appeared on that face, end, or flat side opposite to the corresponding surface in contact with water. It was observed, also, that the upward flow of water by capillarity proceeded at markedly different rates through the various parts of some of the specimens tested.

\section{METHOD OF PROCEDURE}

The bricks were first dried to constant weight. If the bricks absorbed very rapidly (this was always characteristic of the dry-press bricks) so that the tests could be completed within less than 30 minutes with comparatively slight loss from evaporation, the tests were conducted in the air of the laboratory. In case the absorption proceeded more slowly and the error introduced by evaporation from the brick surface above the water became thereby appreciable, the tests were conducted in a chamber, the relative humidity of which was greater than 95 per cent.

The bricks were weighed when completely dry and cool and then set on thin wires in pans containing a measured volume of water at room temperature. This amount of water was so measured that the bricks were each immersed to a depth of $1 / 8$-inch when they were set on end, on face, or flatwise in the pans. At the end of definite time intervals, the bricks were removed from the pan and the wetted portions were wiped with a damp towel, following which the samples were weighed. They were then returned to the pan. A half minute was taken for this complete operation in all cases.

\section{RESULTS}

In Table 5 are given some of the calculated results of these tests made with some of the 10 types of bricks described in Section II. Absorptions were noted, and the values of $C$ were computed for minute intervals in the case of the dry-press bricks and at hour intervals for the more impervious stiff-mud bricks. In order to reduce the size of this table, instead of giving the actual gain in grams during partial immersion ( $1 / 8$ inch) through the edge, end, or flat side of the brick at the end of definite time intervals, there is given for each single brick of a type a value, $C$, at the end of a time interval, $T$. If $W$ equals the gain in grams of water in the brick at the end of a time interval, $T, C=\frac{W}{T^{1 \ell^{3}}}-B T . \quad C$ and $B$ are constants.

As an example, consider the individual specimen No. 3 among brick No. 2 of Table 5. When No. 3 rested on edge in water to a depth of $1 / 8$ inch, the actual gain in weight was as follows: 
This was one of a type of brick that was characterized by a very high rate of absorption. If these numbers are each divided by the cube root of the corresponding time interval, they become-

$$
\begin{aligned}
& \frac{110}{1^{1 / 3}}=110, \quad \frac{197}{4^{1 / 3}}=124, \quad \frac{256}{7^{1 / 3}}=133, \\
& \frac{152}{2^{1 / 3}}=117, \quad \frac{217}{5^{1 / 3}}=127, \text { and } \quad \frac{274}{8^{1 / 3}}=137 . \\
& \frac{174}{3^{1 / 3}}=121, \quad \frac{237}{6^{1 / 3}}=130,
\end{aligned}
$$

It is seen that the rate of change of $\frac{W}{T^{1 / 3}}$ with respect to $T$ is fairly constant; that is, $\frac{d}{d T}\left(\frac{W}{T^{1 / 3}}\right)=$ a constant, $B$. Proceeding from the firstminute interval to the eighth the difference between the respective $\frac{W}{T^{1 / 3}}$ values are $7,4,3,3,3,3$, and 4 . Taking $B$ or $\frac{d}{d T}\left(\frac{W}{T^{1 / 3}}\right)$ as 3 the average of these values obtained graphically, $C$ at the first-minute interval equals $\frac{W_{1}}{T_{1}^{1 / 3}}-B T_{1}=110-3=107 . \quad C$ at the end of the second-minute interval equals $\frac{W_{2}}{T_{2}^{1 / 3}}-B T_{2}=117-6=111$, and so on.

It was found to be generally true that $\frac{d}{d T}\left(\frac{W}{T^{1 / 3}}\right)=$ a constant $B$ (within experimental error) under constant conditions and with a definite surface area of brick in contact with water. Performing the indicated operation, $\frac{d}{d T}\left(\frac{W}{T^{1 / 3}}\right)=\frac{T^{1 / 3} \frac{d W}{d T}-\frac{W T^{-2 / 3}}{3}}{T^{2 / 3}}=B$, this equation reduces to $\frac{d W}{d T}=\frac{W}{3 T}+B T^{1 / 3}$, which is an expression for the actual rate of absorption. Integration of this simple linear differential equation, yields the equation, $C=\frac{W}{T^{1 / 3}}-B T$, where $C$ is a constant of integration.

In the last column throughout Table $5, Y$ has the same meaning as assigned to it in Table 2. It denotes the total absorption of the individual brick when immersed in water at normal room temperature. 
TABLE 5.-Rate of absorption of water by partial immersion (depth of one-eighth inch) of brick

BRICK NO. 2 (SET ON EDGE)

\begin{tabular}{|c|c|c|c|c|c|c|c|c|c|c|c|}
\hline \multirow{2}{*}{ Sample No. } & \multirow{2}{*}{$B$} & \multicolumn{9}{|c|}{$C=\frac{W}{T^{1 / 3}}-B T$} & \multirow{2}{*}{$\begin{array}{c}\text { Total } \\
\text { grams of } \\
\text { water } \\
\text { absorbed } \\
Y\end{array}$} \\
\hline & & 1 min- & 2 min- & $\begin{array}{c}3 \text { min- } \\
\text { utes }\end{array}$ & 4 min- & 5 min- & $\begin{array}{l}6 \text { min- } \\
\text { utes }\end{array}$ & 7 min- & $\begin{array}{l}8 \mathrm{~min}- \\
\text { utes }\end{array}$ & $\begin{array}{c}10 \text { min- } \\
\text { utes }\end{array}$ & \\
\hline 3 & 3.0 & $10 \pi$ & 114 & 112 & 112 & 112 & 112 & 112 & 113 & & 282 \\
\hline 208 & 3.0 & 102 & 104 & 104 & 103 & 103 & 102 & 101 & 101 & & 295 \\
\hline 175 & 4.0 & 104 & 108 & 109 & 109 & 107 & 106 & 105 & 104 & & 296 \\
\hline 214 & 2.3 & 120 & 121 & 122 & 118 & 122 & 122 & 122 & 122 & & 296 \\
\hline 144 & 1.0 & 102 & 104 & 103 & 103 & 104 & 104 & 103 & 104 & & 274 \\
\hline 74 & 2.0 & 92 & 94 & 95 & 95 & 95 & 95 & 95 & 93 & & 242 \\
\hline 155 & 2.7 & 85 & 86 & 87 & 86 & 86 & 85 & 84 & 84 & & 222 \\
\hline 24 & 2.3 & 85 & 85 & 87 & 88 & 87 & 86 & 85 & 85 & & 217 \\
\hline 127. & 2.6 & 49 & 52 & 51 & 54 & 53 & 51 & 50 & 49 & & 210 \\
\hline 12 & 2.3 & 69 & 69 & 70 & 70 & 70 & 73 & 70 & 69 & & 203 \\
\hline 210 & 2.0 & 79 & 81 & 83 & 83 & 82 & 81 & 81 & 80 & & 202 \\
\hline 111 & 2.3 & 57 & 60 & 60 & 60 & 60 & 59 & 58 & 57 & & 196 \\
\hline 171 & 1. 0 & 53 & 47 & 49 & 50 & 50 & 51 & 51 & 51 & & 171 \\
\hline & & 47 & 50 & 42 & 44 & 43 & 44 & 46 & 46 & 46 & 156 \\
\hline
\end{tabular}

BRICK NO. 3 (SET ON EDGE)

\begin{tabular}{|c|c|c|c|c|c|c|c|c|c|c|}
\hline \multirow{2}{*}{ Sample No. } & \multirow{2}{*}{$B$} & \multicolumn{8}{|c|}{$C=\frac{W}{T 1 / 3}-B T$} & \multirow{2}{*}{$\begin{array}{c}\text { Total } \\
\text { grams of } \\
\text { water } \\
\text { absorbed } \\
Y\end{array}$} \\
\hline & & 1 hour & 2 hours & 3 hours & 4 hours & 5 hours & 6 hours & 7 hours & 8 hours & \\
\hline 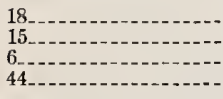 & $\begin{array}{l}2.0 \\
3.0 \\
2.5 \\
2.7\end{array}$ & $\begin{array}{l}80 \\
70 \\
64 \\
60\end{array}$ & $\begin{array}{l}81 \\
72 \\
68 \\
62\end{array}$ & $\begin{array}{l}79 \\
71 \\
66 \\
62\end{array}$ & $\begin{array}{l}79 \\
70 \\
67 \\
64\end{array}$ & $\begin{array}{l}81 \\
72 \\
66 \\
62\end{array}$ & $\begin{array}{l}80 \\
72 \\
65 \\
62\end{array}$ & & & $\begin{array}{l}191 \\
180 \\
172 \\
164\end{array}$ \\
\hline $\begin{array}{l}54 \\
110 \\
111\end{array}$ & $\begin{array}{l}2.4 \\
2.5 \\
2.2 \\
2.0\end{array}$ & $\begin{array}{l}54 \\
47 \\
48 \\
42\end{array}$ & $\begin{array}{l}55 \\
49 \\
47 \\
44\end{array}$ & $\begin{array}{l}54 \\
48 \\
49 \\
44\end{array}$ & $\begin{array}{l}56 \\
48 \\
50 \\
43\end{array}$ & $\begin{array}{l}53 \\
49 \\
47 \\
42\end{array}$ & $\begin{array}{l}53 \\
47 \\
47 \\
44\end{array}$ & & & $\begin{array}{l}153 \\
140 \\
138 \\
132\end{array}$ \\
\hline $\begin{array}{l}32 \\
101 \\
73 \\
38 \\
38 .\end{array}$ & $\begin{array}{l}1.8 \\
2.1 \\
1.6 \\
1.5\end{array}$ & $\begin{array}{l}40 \\
33 \\
26 \\
23\end{array}$ & $\begin{array}{l}42 \\
34 \\
28 \\
26\end{array}$ & $\begin{array}{l}41 \\
34 \\
28 \\
25\end{array}$ & $\begin{array}{l}42 \\
34 \\
29 \\
25\end{array}$ & $\begin{array}{l}40 \\
33 \\
26 \\
26\end{array}$ & $\begin{array}{l}38 \\
35 \\
28 \\
26\end{array}$ & & & $\begin{array}{r}123 \\
115 \\
96 \\
90\end{array}$ \\
\hline $\begin{array}{l}81 \\
74 \\
30 \\
84\end{array}$ & $\begin{array}{l}2.3 \\
0.8 \\
0.0 \\
0.3\end{array}$ & $\begin{array}{r}22 \\
18 \\
14 \\
9\end{array}$ & $\begin{array}{l}24 \\
20 \\
14 \\
11\end{array}$ & $\begin{array}{l}25 \\
19 \\
13 \\
11\end{array}$ & $\begin{array}{l}24 \\
20 \\
14 \\
13\end{array}$ & $\begin{array}{l}26 \\
20 \\
14 \\
11\end{array}$ & $\begin{array}{l}24 \\
21 \\
12 \\
10\end{array}$ & $\begin{array}{l}21 \\
14 \\
13\end{array}$ & 11 & $\begin{array}{l}88 \\
73 \\
62 \\
49\end{array}$ \\
\hline
\end{tabular}

BRICK NO. 4 (SET ON END)

\begin{tabular}{|c|c|c|c|c|c|c|c|c|c|c|}
\hline \multirow{2}{*}{$\begin{array}{c}\text { Sample } \\
\text { No. }\end{array}$} & \multirow{2}{*}{$B$} & \multicolumn{8}{|c|}{$\mathrm{C}=\frac{\mathrm{W}}{T^{1 / 3}}-B T$} & \multirow{2}{*}{$\begin{array}{c}\text { Total } \\
\text { grams of } \\
\text { water } \\
\text { absorbed } \\
Y\end{array}$} \\
\hline & & 1 min- & $\begin{array}{l}2 \text { min- } \\
\text { utes }\end{array}$ & $\begin{array}{l}3 \text { min- } \\
\text { utes }\end{array}$ & 4 min- & 5 min- & 6 min- & 7 min- & $\begin{array}{l}8 \text { min- } \\
\text { utes }\end{array}$ & \\
\hline $\begin{array}{l}108 \\
95 \\
110 \\
147 \\
146 \\
100\end{array}$ & $\begin{array}{l}1.0 \\
0.0 \\
1.0 \\
1.0 \\
1.4 \\
0.4\end{array}$ & $\begin{array}{l}39 \\
38 \\
46 \\
35 \\
33 \\
31\end{array}$ & $\begin{array}{l}39 \\
37 \\
47 \\
35 \\
33 \\
32\end{array}$ & $\begin{array}{l}39 \\
37 \\
47 \\
36 \\
33 \\
32\end{array}$ & $\begin{array}{l}39 \\
38 \\
47 \\
36 \\
33 \\
31\end{array}$ & $\begin{array}{l}39 \\
38 \\
47 \\
37 \\
34 \\
31\end{array}$ & $\begin{array}{r}39 \\
38 \\
47 \\
37 \\
34 \\
33\end{array}$ & $\begin{array}{l}39 \\
38 \\
47 \\
37 \\
33 \\
32\end{array}$ & $\begin{array}{l}39 \\
39 \\
47 \\
37 \\
33 \\
33\end{array}$ & $\begin{array}{r}130 \\
98 \\
129 \\
123 \\
117 \\
98\end{array}$ \\
\hline
\end{tabular}


TABLE 5.-Rate of absorption of water by partial immersion (depth of one-eighth inch) of brick-Continued

BRICK NO. 9 (SET ON END)

\begin{tabular}{|c|c|c|c|c|c|c|c|}
\hline \multirow{2}{*}{ Sample No. } & \multirow{2}{*}{$B$} & \multicolumn{5}{|c|}{$C=\frac{W}{T^{1 / 3}}-B T$} & \multirow{2}{*}{$\begin{array}{c}\text { Total } \\
\text { grams of } \\
\text { water } \\
\text { absorbed } \\
Y\end{array}$} \\
\hline & & 1 hour & 2 hours & 3 hours & 4 hours & 5 hours & \\
\hline $\begin{array}{l}213 \\
48 \\
168 \\
169\end{array}$ & $\begin{array}{l}3.1 \\
1.4 \\
2.4 \\
2.3 \\
2.3\end{array}$ & $\begin{array}{l}28 \\
28 \\
24 \\
20 \\
28\end{array}$ & $\begin{array}{l}30 \\
30 \\
25 \\
22 \\
28\end{array}$ & $\begin{array}{l}30 \\
29 \\
24 \\
22 \\
28\end{array}$ & $\begin{array}{l}29 \\
28 \\
24 \\
20 \\
28\end{array}$ & $\begin{array}{l}28 \\
29 \\
24 \\
20 \\
28\end{array}$ & $\begin{array}{l}135 \\
131 \\
125 \\
124 \\
122\end{array}$ \\
\hline $\begin{array}{l}201 \\
142 \\
62\end{array}$ & $\begin{array}{l}1.8 \\
0.1 \\
0.5\end{array}$ & $\begin{array}{r}23 \\
5 \\
6\end{array}$ & $\begin{array}{r}25 \\
4 \\
5\end{array}$ & $\begin{array}{r}24 \\
4 \\
5\end{array}$ & $\begin{array}{r}24 \\
5 \\
4\end{array}$ & $\begin{array}{r}23 \\
5 \\
5\end{array}$ & $\begin{array}{r}118 \\
64 \\
60\end{array}$ \\
\hline
\end{tabular}

BRICK NO. 9 (SET ON FLAT SIDE)

\begin{tabular}{|c|c|c|c|c|c|c|c|}
\hline 209 & $\begin{array}{l}2.4 \\
6.0\end{array}$ & $\begin{array}{l}24 \\
42\end{array}$ & $\begin{array}{l}23 \\
45\end{array}$ & $\begin{array}{l}23 \\
44\end{array}$ & $\begin{array}{l}24 \\
42\end{array}$ & 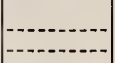 & $\begin{array}{l}104 \\
125\end{array}$ \\
\hline $\begin{array}{l}45 \\
506 \\
504\end{array}$ & $\begin{array}{l}3.8 \\
3.8 \\
3.2 \\
0.0\end{array}$ & $\begin{array}{l}30 \\
26 \\
27 \\
17\end{array}$ & $\begin{array}{l}31 \\
27 \\
27 \\
17\end{array}$ & $\begin{array}{l}31 \\
27 \\
27 \\
18\end{array}$ & $\begin{array}{l}32 \\
27 \\
27 \\
17\end{array}$ & $\begin{array}{l}31 \\
26 \\
27 \\
18\end{array}$ & $\begin{array}{r}123 \\
107 \\
98 \\
81\end{array}$ \\
\hline 120 & $\begin{array}{l}2.0 \\
0.3 \\
1.8 \\
0.6\end{array}$ & $\begin{array}{l}41 \\
13 \\
43 \\
17\end{array}$ & $\begin{array}{l}45 \\
12 \\
44 \\
18\end{array}$ & $\begin{array}{l}47 \\
12 \\
46 \\
17\end{array}$ & $\begin{array}{l}44 \\
12 \\
45 \\
18\end{array}$ & $\begin{array}{l}41 \\
13 \\
43 \\
17\end{array}$ & $\begin{array}{r}115 \\
97 \\
111 \\
105\end{array}$ \\
\hline
\end{tabular}

BRICK NO. 5 (SET ON END)

\begin{tabular}{|c|c|c|c|c|c|c|c|c|c|c|c|c|c|c|}
\hline \multirow[b]{2}{*}{ Sample No. } & \multirow[b]{2}{*}{$\boldsymbol{B}$} & \multicolumn{12}{|c|}{$C=\frac{W}{T^{1 / 3}}-B T$} & \multirow{2}{*}{$\begin{array}{c}\text { Total } \\
\text { grams } \\
\text { of } \\
\text { water } \\
\text { ab- } \\
\text { sorb- } \\
\text { ed } \\
Y\end{array}$} \\
\hline & & min- $_{\text {ute }}^{1}$ & $\underset{\text { utes }}{2}$ & $\underset{\text { utes }}{3}$ & $\frac{4}{\text { min- }}$ & $\begin{array}{l}5 \\
\text { min- } \\
\text { utes }\end{array}$ & $\begin{array}{c}6 \\
\text { min- } \\
\text { utes }\end{array}$ & $\frac{7}{\text { min- }}$ & 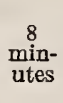 & $\begin{array}{c}10 \\
\text { min- } \\
\text { utes }\end{array}$ & $\begin{array}{c}12 \\
\text { min- } \\
\text { utes }\end{array}$ & $\begin{array}{c}15 \\
\text { min- } \\
\text { utes }\end{array}$ & $\begin{array}{c}30 \\
\text { min- } \\
\text { utes }\end{array}$ & \\
\hline 142 & $\begin{array}{l}0.4 \\
0.3\end{array}$ & $\begin{array}{l}23 \\
20\end{array}$ & $\begin{array}{l}22 \\
21\end{array}$ & $\begin{array}{l}22 \\
22\end{array}$ & $\begin{array}{l}23 \\
22\end{array}$ & $\begin{array}{l}23 \\
23\end{array}$ & $\begin{array}{l}24 \\
22\end{array}$ & $\begin{array}{l}23 \\
23\end{array}$ & $\begin{array}{l}23 \\
23\end{array}$ & $\begin{array}{l}23 \\
23\end{array}$ & $\begin{array}{l}23 \\
23\end{array}$ & $\begin{array}{l}22 \\
24\end{array}$ & $\begin{array}{l}22 \\
22\end{array}$ & $\begin{array}{l}211 \\
270\end{array}$ \\
\hline
\end{tabular}

BRICK NO. 5 (SET ON EDGE)

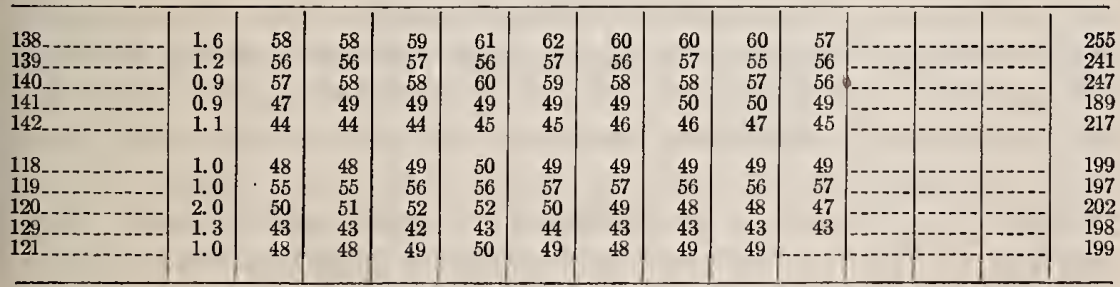


TABLE 5.-Rate of absorption of water by partial immersion (depth of one-eighth inch) of brick-Contiuned

BRICK NO. 10 (SET ON EDGE)

\begin{tabular}{|c|c|c|c|c|c|c|c|c|c|}
\hline \multirow{2}{*}{$\begin{array}{l}\text { Sample } \\
\text { No. }\end{array}$} & \multirow{2}{*}{$B$} & \multicolumn{7}{|c|}{$C=\frac{W}{T^{1 / 3}}-B T$} & \multirow{2}{*}{$\begin{array}{c}\begin{array}{c}\text { Total } \\
\text { grams of } \\
\text { water } \\
\text { absorbed }\end{array} \\
Y\end{array}$} \\
\hline & & 1 hour & 2 hours & 3 hours & 4 hours & 5 hours & 8 hours & 16 hours & \\
\hline $\begin{array}{l}151 \\
100 \\
53 \\
32\end{array}$ & 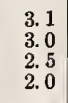 & $\begin{array}{l}47 \\
42 \\
31 \\
25\end{array}$ & $\begin{array}{l}49 \\
42 \\
33 \\
26\end{array}$ & $\begin{array}{l}49 \\
40 \\
33 \\
27\end{array}$ & $\begin{array}{l}50 \\
40 \\
32 \\
27\end{array}$ & $\begin{array}{l}49 \\
42 \\
31 \\
26\end{array}$ & $\begin{array}{l}47 \\
42 \\
33 \\
27\end{array}$ & & $\begin{array}{l}154 \\
141 \\
125 \\
110\end{array}$ \\
\hline $\begin{array}{l}25 \\
52 \\
133 \\
146\end{array}$ & $\begin{array}{l}2.1 \\
1.9 \\
2.0 \\
1.6\end{array}$ & $\begin{array}{l}23 \\
19 \\
16 \\
14\end{array}$ & $\begin{array}{l}23 \\
20 \\
17 \\
15\end{array}$ & $\begin{array}{l}23 \\
21 \\
17 \\
15\end{array}$ & $\begin{array}{r}.24 \\
21 \\
18 \\
15\end{array}$ & $\begin{array}{l}23 \\
20 \\
17 \\
14\end{array}$ & $\begin{array}{l}24 \\
20 \\
17 \\
14\end{array}$ & & $\begin{array}{r}100 \\
94 \\
83 \\
75\end{array}$ \\
\hline $\begin{array}{l}138 \\
204 \\
205 \\
143\end{array}$ & $\begin{array}{l}1.0 \\
0.7 \\
0.0 \\
0.3\end{array}$ & $\begin{array}{r}12 \\
12 \\
8 \\
7\end{array}$ & $\begin{array}{r}14 \\
12 \\
9 \\
8\end{array}$ & $\begin{array}{r}14 \\
13 \\
9 \\
8\end{array}$ & $\begin{array}{r}13 \\
12 \\
9 \\
8\end{array}$ & $\begin{array}{r}13 \\
12 \\
8 \\
7\end{array}$ & $\begin{array}{r}13 \\
12 \\
9 \\
9\end{array}$ & $\begin{array}{r}12 \\
8 \\
8\end{array}$ & $\begin{array}{l}71 \\
63 \\
50 \\
47\end{array}$ \\
\hline
\end{tabular}

\section{DISCUSSION OF RESULTS}

The relation, $C=\frac{W}{T^{1 / 3}}-B T$, where $C$ and $B$ are constants and $W$ is the gain in weight at the end of any time interval, $T$, is characteristic of individual bricks studied. The values of the constants $B$ and $C$ were different for different bricks, and different values for these constants were evaluated from the data obtained by exposing the different surfaces (end, face, or flat side) of any one brick to water. This relation may not be applicable to the absorption rate of a clay body that is distinctly underburned or overburned.

Since $B=\frac{d}{d T}\left(\frac{W}{T^{1 / 3}}\right)$ and since $\frac{W}{T^{1 / 3}}=T^{2 / 3} \times W / T=T^{2 / 3}$ times the average rate of absorption during the time interval, $T$, it is seen that $B$ equals the rate of change with respect to time of $T^{2 / 3} \times$ average rate. $C=T^{2 / 3} \times W / T-B T=T^{2 / 3} \times$ the average rate of absorption during the time interval, $T$, minus a constant times the time. $C$ is fairly constant over a more or less definite time interval. The relation ceases to apply after water strikes through. After water has traveled through the entire length, breadth, or thickness of the clay brick, the rate of absorption decreases markedly. It is also seen from Table 5 that the magnitude of $C$ for any single brick of one type is usually greater, the greater the magnitude of $Y$, the total apparent cold absorption. This relation between $C$ and $Y$ is illustrated in Figure 3. While it is seen that in Table 5 the magnitude of $C$ generally increases as that of $Y$ increases, it may also be noted that there are many exceptions to this rule. This rule applies best to bricks Nos. 3 and 10. No. 24 of brick 2 having a $C$ of 51 has a $Y$ of 210 , whereas Nos. 12 and 210, each having a smaller $Y$ than No. 24, have larger $C^{\prime}$ 's. 
There are many other exceptions to be noted. These differences are due mainly to differences of permeability of surface; for example, the surface of No. 24 is apparently more flashed than the surfaces of Nos. 12 and 210. By grinding off the exterior surfaces it is possible to reduce these differences to a considerable extent. However, it was necessary to study the absorption rates of the bricks as they are made and not as modified in the laboratory.

The statement that the magnitude of $C$ usually decreases as the magnitude of $Y$ decreases might have more meaning were it restated as follows: Among bricks made from the same clay or shale and by

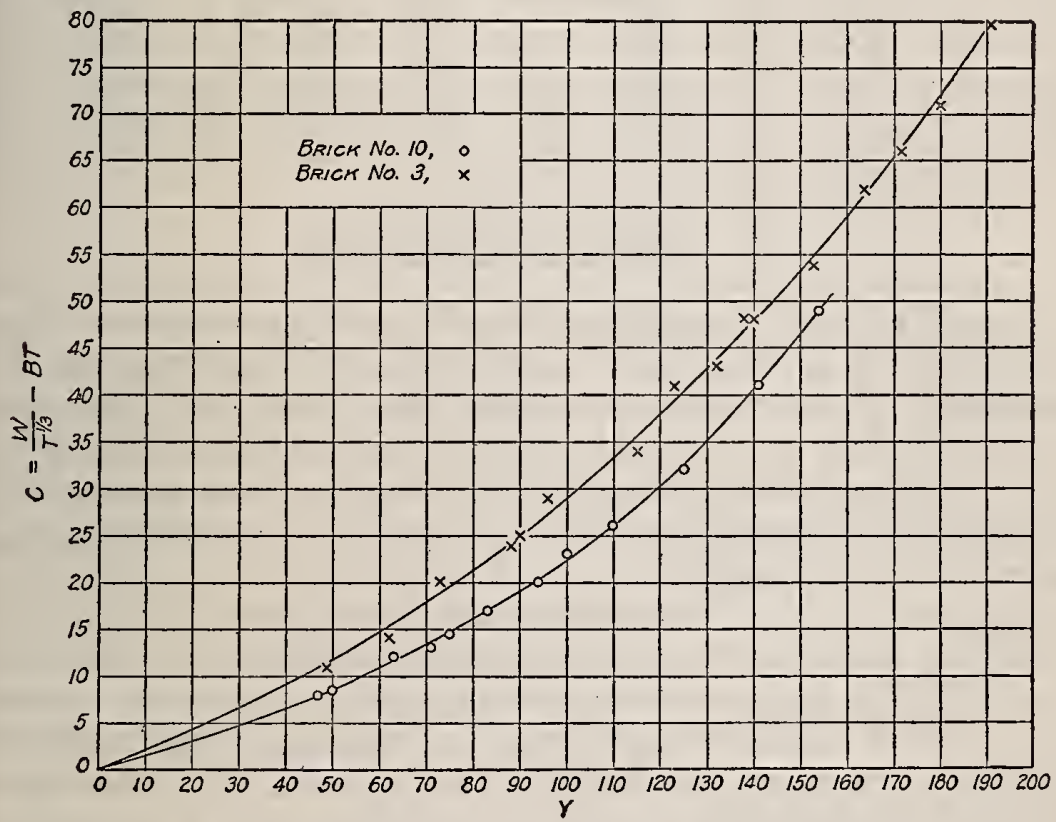

FrgURE 3.-The more highly absorbent brick of a type have usually higher $C$ values

the same process of manufacture, the more highly absorbent bricks usually absorb relatively more rapidly and the less absorbent bricks, of course, usually absorb relatively more slowly. The reader is warned not to interpret this as applying to bricks in general. If the 10 different manufacturers' bricks were all mixed together in one pile, this rule would not apply to the pile. It would apply to all of any particular manufacturer's bricks in that pile.

In the belief that this point has some importance from the standpoint of transmission of water into a wall of bricks, the actual data concerning the rates of absorption of the individual bricks of brick No. 10 are given in Table 6 . Computations of these data were given in Table 5. 
TABLE 6.-Absorption of water (grams) by partial immersion (depth of one-eighth inch) of brick set on edge

BRICK NO. 10

\begin{tabular}{|c|c|c|c|c|c|c|c|c|c|}
\hline $\begin{array}{c}\text { Sample } \\
\text { No. }\end{array}$ & 1 hour & 2 hours & 3 hours & 4 hours & 5 hours & 8 hours & 16 hours & $\begin{array}{c}\text { Total } \\
\text { grams } \\
\underset{Y}{\text { absorbed, }}\end{array}$ & $\begin{array}{l}\text { Per cent } \\
\text { of } Y \\
\text { gained in } \\
8 \text { hours }\end{array}$ \\
\hline $\begin{array}{l}151 \\
100 \\
53 \\
32\end{array}$ & $\begin{array}{l}50 \\
45 \\
33 \\
27\end{array}$ & $\begin{array}{l}71 \\
61 \\
48 \\
38\end{array}$ & $\begin{array}{l}84 \\
74 \\
58 \\
48\end{array}$ & $\begin{array}{l}99 \\
83 \\
67 \\
56\end{array}$ & $\begin{array}{r}110 \\
97 \\
74 \\
62\end{array}$ & $\begin{array}{r}143 \\
132 \\
106 \\
86\end{array}$ & $\begin{array}{l}(1) \\
(1) \\
(1) \\
(1)\end{array}$ & $\begin{array}{l}154 \\
142 \\
125 \\
110\end{array}$ & $\begin{array}{l}92.9 \\
93.0 \\
84.8 \\
78.2\end{array}$ \\
\hline $\begin{array}{l}25 \\
52 \\
133 \\
146\end{array}$ & $\begin{array}{l}25 \\
21 \\
18 \\
16\end{array}$ & $\begin{array}{l}34 \\
30 \\
26 \\
23\end{array}$ & $\begin{array}{l}42 \\
39 \\
33 \\
29\end{array}$ & $\begin{array}{l}51 \\
45 \\
41 \\
34\end{array}$ & $\begin{array}{l}57 \\
50 \\
46 \\
38\end{array}$ & $\begin{array}{l}82 \\
70 \\
64 \\
54\end{array}$ & $\begin{array}{l}\text { (1) } \\
(1) \\
\text { (1) } \\
\text { (1) }\end{array}$ & $\begin{array}{r}100 \\
94 \\
83 \\
75\end{array}$ & $\begin{array}{l}82.0 \\
74.4 \\
77.1 \\
72.0\end{array}$ \\
\hline $\begin{array}{l}138 \\
204 \\
205 \\
143\end{array}$ & $\begin{array}{r}13 \\
13 \\
8 \\
7\end{array}$ & $\begin{array}{l}20 \\
17 \\
11 \\
11\end{array}$ & $\begin{array}{l}25 \\
22 \\
13 \\
13\end{array}$ & $\begin{array}{l}27 \\
23 \\
14 \\
15\end{array}$ & $\begin{array}{l}31 \\
27 \\
14 \\
15\end{array}$ & $\begin{array}{l}42 \\
35 \\
18 \\
23\end{array}$ & (1) $\begin{array}{l} \\
58 \\
20 \\
32\end{array}$ & $\begin{array}{l}71 \\
63 \\
50 \\
47\end{array}$ & $\begin{array}{l}59.2 \\
55.6 \\
36.0 \\
49.0\end{array}$ \\
\hline
\end{tabular}

1 Water struck through to opposite face shortly after eight hours.

\section{GENERAL DISCUSSION}

There is evidence that with prolonged immersion in water at room temperature a clay brick will continue to absorb water more or less indefinitely until it has finally absorbed the same or nearly the same amount of water that it would absorb during a period of hours when kept in boiling water. Douty ${ }^{6}$ has reported results obtained by keeping bricks immersed in water at normal room temperature for a period of 110 consecutive days.

Such tests were not repeated in this investigation. The author has noted, however, from results obtained by immersing bricks for a period of two weeks in water at normal and fairly constant temperature, that a relatively rapid rate of absorption which continues from 24 to 120 hours, varying from one type of brick to another, is followed by a much slower and more constant rate of absorption. The following explanation for this behavior is offered. Water enters the voids of the burned-clay body rapidly at first, then at a diminishing rate until the resultant of the forces, hydrostatic pressure, surface tension, etc., is balanced by the opposed pressure of entrapped air in the voids. Further absorption then proceeds very, very slowly, if the temperature of the water remains constant, through the gradual diffusion of this entrapped air. Under these conditions the brick absorbs less than a gram of additional water during 24 hours. As soon as this slow rate of absorption is attained it is conceivable that a condition of apparent or "pseudo" equilibrium exists.

It is difficult to account for this diffusion of air unless it is assumed that it dissolves in the water which partially fills the voids and so

${ }^{6}$ D. E. Douty and L. L. Beebe, Proc. Am. Soc. Testing Materials, 11, p. 767; 1911. 
makes its escape. However, the water is probably already saturated with air. It must be realized that this is only a theory.

An increase in the temperature of the water would result in a lower solubility of air in water and a decrease in the surface tension of that liquid. The apparent equilibrium would, therefore, be displaced. The viscosity of the water would also be reduced, and the frictionalwall resistance opposing its flow into the voids would be decreased. The following is an experimental fact: If a brick is immersed in water at $25^{\circ} \mathrm{C}$. for a period of time such that the rate of gain in weight by absorption becomes less than $1 \mathrm{~g}$ during 24 hours and if it is then transferred to water at $75^{\circ} \mathrm{C}$. and held therein for a half hour or more, then placed again in the water at $25^{\circ} \mathrm{C}$., it will be found that, after cooling in the latter, the amount of water which it then contains is appreciably more than that contained prior to transferring the specimen to the water at the higher temperature. This would indicate that a displacement of some of the entrapped air takes place when immersed in the warmer water. Water vapor takes the place of some of the entrapped air, and upon subsequent cooling in water at $25^{\circ} \mathrm{C}$. some of this water vapor is condensed in the voids, and the pressure of the entrapped air is thereby reduced, allowing more water to enter.

There are a number of mathematical equations pertaining to the time-distance relationships that apply to the flow of water in material already wetted or containing water. However, penetration of water into perfectly dry material is not so well understood. This is the condition that exists when a perfectly dry clay brick is partially immersed in water at a definite temperature. Capillary attraction, rate of viscous flow, and wetting of surface are all involved, and the problem is an exceedingly complicated one.

It has been noted that certain of the dry-press bricks tested absorbed water far more rapidly than did bricks molded by the stiffmud process from the same clay or shale used in making the drypress bricks. It would be expected that the pores of dry-press bricks would tend to be larger than those in bricks molded by the stiff-mud process from the same clay or shale, were the conditions of drying and burning of the two types of bricks identical.

During this investigation no attempt has been made to aeduce from any theory these simple empirical equations that within the limits of experimental error apply to the data. It might, of course, be assumed that the pores in a clay brick are cylindrical and open at both ends or that they are conical in shape and closed at one end, or it may be assumed that the solid'particles are spherical, packed, and more or less sintered together. On the basis of such assumptions a variety of equations may be deduced which may or may not be a 
true picture of the mechanics of the process, absorption. In this investigation no such assumptions were made, but absorption measurements were made and the data analyzed. Certain simple empirical equations were seen to fit these data rather nicely.

It should be mentioned that in conducting such tests as the above and in the application of such methods of computation of the data obtained it will be found that the more a brick is laminated, checked, cracked, and filled with pebbles, etc., the more it will deviate from this somewhat symmetrical behavior. Deviations from the absorption constant, $K$, on the part of individual bricks of a type are considerably less if the burned-clay bodies are as nearly "homogeneous" as may be expected of such material. It is also probable that deviations may result from the addition of grog, fluxes, etc., to the clay.

\section{GENERAL SUMMARY}

1. The absorption properties of 10 different types of clay bricks have been studied.

2. Certain simple empirical equations fit these absorption data within the limits of experimental error.

3. Three constants have been evaluated. Two of these, $B$ and $C$, are derived by a method of computation of the data obtained in the study of rate of absorption by partially immersing bricks in water. The third, the absorption constant, $K$, is obtained by immersing the brick in water at normal room temperature for a more or less definite period of time and following this by immersion in boiling water for a period of seven hours. The Schurecht ratio, slightly modified, is used in evaluating $K$ for any type of brick.

4. It is indicated that the constants, $B, C$, and $K$, are more characteristic of a given clay or shale from which a type of brick is made than they are of any other single thing.

5. The absorption constant, $K$, is independent of the heat treatment that the clay body has received over a certain limited range in the burning temperature.

6. It may be possible to relate the absorption constant, $K$, characteristic of a manufacturer's brick, to the weather resistance of that material, and this constant and the others, $B$ and $C$, may furthermore be of use in differentiating between underburned and overburned bricks on the one hand and well burned on the other. However, in the absence of any actual data, this is a matter of conjecture only. These constants will be studied in any future work here involving weather resistance or differentiating between degrees of burning. It is believed they will be of particular value in the study now under way of the process of water penetration through brick masonry. 


\section{ACKNOWLEDGMENTS}

The writer wishes to extend his thanks to Messrs. Bates, Parsons, and McBurney for many helpful suggestions and criticisms given by them during the course of this study. Gratitude is especially due William C. Koch, president of the American Face Brick Association, for many valuable suggestions and particularly for advising the author to compute all absorption data on the basis of volume alone. The cooperation of the various members of the face and common brick associations who furnished the materials for the study is also deeply appreciated.

Washington, March 15, 1929.

$53811^{\circ}-29-9$ 